\title{
Community-Oriented Protected Areas for Indigenous Peoples and Local Communities ${ }^{1}$
}

\author{
Marcia Langton, University of Melbourne ${ }^{2}$ \\ Zane Ma Rhea, Monash University \\ Lisa Palmer, University of Melbourne
}

\section{Acronyms}

ALRA: Aboriginal Land Rights Act (Northern Territory) 1976 (Cth.)

ALT: (South Australia) Aboriginal Lands Trust

AMAN: Aliansi Masyarakat Adat Indonesia (Alliance of Archipelagic Indigenous Peoples)

CBD: Convention of Biological Diversity

CCAs: Community Conserved Areas

DLMAC: Dhimurru Land Management Aboriginal Corporation

IBRA: Interim Biogeographic Regionalisation of Australia

IK: Indigenous Knowledge

IPA: Indigenous Protected Area

IUCN: International Union for the Conservation of Nature NBSAPs:

NHT: Natural Heritage Trust

NRS: National Reserve System

UNESCO: United Nations Educational, Scientific and Cultural Organization

\section{Introduction}

Do indigenous peoples engage with their environments only as small-scale consumers, in which the conservation of species or habitats is an incidental outcome? Furthermore, is it the case as some have argued, that modern conservation is based on a global ethic of responsibility, whereas indigenous peoples are concerned only with localised practices and contexts? In order to answer these questions, this paper is critical of these and other tropes (or stereotypes) of indigenous peoples which, we argue, are appropriated by conservationists for their own ends, and which have a significant influence on the public perception of indigenous engagement with biodiversity conservation. We argue that despite these stereotypes, it is not the case that Indigenes are merely pawns or bystanders in conservation processes. Rather, across the globe, indigenous people are actively engaging in environmental planning processes at a variety of scales. As one of us has written elsewhere:

If we admit that Aboriginal people are fully sentient and intellectual beings, we can admit that they would engage with the effects of the global economy and information society, and that they would bring to these problems interesting and innovative approaches. Sustainable use of natural resources presents options for evolving Aboriginal approaches to the stewardship of their estates (M.Langton 1998: 29).

These emerging indigenous approaches to biodiversity conservation are referred to by Anna Tsing (2005) in her work on the circulation of discourses within and between remote Indonesian villages, provincial and national capitals and international conservation networks. She discusses the 'friction' created through the 'engaged universals' which play out across the globe around a discourse of 'nature'. Writing about the 'productivity of difference' in multiscalar environmental and political projects which promote community-based natural resource management, Tsing observes:

1. This paper is dedicated to the late Mr N. Munungguritj and the late Mr. Steve Szabo.

2. Marcia Langton holds the Chair of Australian Indigenous Studies at The University of Melbourne, Australia: marciall@unimelb.edu.au. Zane Ma Rhea is a Lecturer in the Faculty of Education at Monash University, Australia. Lisa Palmer is a Lecturer in the School of Anthropology, Geography and Environmental Studies (SAGES) at The University of Melbourne. The authors would like to acknowledge the following people who have had input in some way into this paper: Margaret Ayre, Juanita Pope, the late Steve Szabo, Bruce Rose, Kelvin Leitch, Steve Roeger, Simon Batterbury and two anonymous reviewers. All errors and omissions remain the responsibility of the authors. 
I'm not sure these initiatives will work, and I'm sure they won't bring justice to everyone. They embroil participants in debates about authenticity and consensus. They mess with-or displace-earlier categories and cosmologies; they realign local priorities. They require what Levi and Dean (2003) call the 'risk' of indigeneity, that is, the strategic transformation of local identity to enter a wider conversation. To be taken seriously by national and imperial interlocutors requires some such risk (2005: 267-268).

In many instances these are risks that indigenous groups have either consciously chosen, or have little choice, but to take. In this paper we examine the emerging practice of establishing community-oriented protected areas, with special reference to the Indigenous Protected Areas (IPA) program in Australia. We examine the ways in which such areas can contribute to supporting the lifeways of indigenous peoples and local communities, assist in the preservation and maintenance of their traditional biodiversity related knowledge, and enable indigenous peoples and local communities to participate in both customary subsistence and market economies. We examine the developing international frameworks for communityoriented protected areas and selected responses to such initiatives in Australia and to a more limited extent in Asia. In Australia we focus on the example of indigenous governance arrangements in the federally funded IPA program. We argue that guaranteed land security and the ability of indigenous and local peoples to exercise their own governance structures is central to the success of the Australian example. We also argue, in contrast to many critiques of community-based conservation elsewhere, that community-oriented protected areas are delivering significant benefits to indigenous peoples in Australia.

Two IPA cases are examined in more detail to provide an account of indigenous peoples' efforts and capacity to protect, promote and facilitate the use of their traditional estates and knowledge under the control of indigenous modes of governance, engaging, when necessary, with the government and non-government agencies which they believe can assist them in achieving particular land management and livelihood goals. Along with the strengthening of traditional modes of governance and sustainable land management regimes, we argue that the benefits accruing to indigenous peoples and local communities from participation in community-oriented and, most crucially, community controlled protected areas initiatives can include the preservation, renewal and maintenance of the knowledge systems upon which indigenous livelihoods and environmental security depends. Our research data results from two projects, one which collects together the Australian material on Indigenous Protected Areas, the other a major survey of biodiversity-related traditional knowledge, innovations and practices of indigenous and local communities in the Middle East, Asia and Australia. ${ }^{3}$

\section{Traditional Livelihoods and Biodiversity}

A growing literature has recognised the role of traditional knowledges and practices in preserving biodiversity (D.Ghai, 1994; M.Ferarri 2003; L.Maffi 2001; E.Mathias 1994, 1995; J.Matowanyika et al. 1995; P.Maundu, 1995; B.Nietschmann 1992; D.Posey 2003; P.Richards 1995). For indigenous peoples and local communities, concern about the preservation and maintenance of traditional knowledge is not only motivated by the desire to conserve 'biodiversity' as an end in itself, but also by the desire to live on their ancestral lands, to safeguard local food security and, to the extent possible, exercise local economic, cultural and political autonomy (see for instance, M.Langton 2003). In small-scale agricultural societies for instance, traditional methods of irrigation and crop production, and maintenance of seed stock and cultivars, have maintained food and grazing resources. Traditional water management systems have been critical to societies across all ecosystems.

In economically developed nations such as Australia and Japan, many indigenous peoples are dependent on traditional knowledge and practices in caring for their traditional

3 This paper draws on several research projects. These include an Australian Research Council Linkage Project, 'Agreements, Treaties and Negotiated Settlements with Indigenous Peoples in Settler States: Their Role and Relevance for Indigenous and Other Australians' (www.atns.net.au). This project involved researchers from an industry partner, the Aboriginal and Torres Strait Islander Commission, from The University of Melbourne (Associate Professor Maureen Tehan, Faculty of Law) and The University of Technology, Sydney (Professor Larissa Behrendt, Faculty of Law and the Jumbunna Indigenous House of Learning). The Australian Institute of Aboriginal and Torres Strait Islander Studies also lent support, and we draw on a report prepared for the Secretariat of the Convention on Biological Diversity by Langton and Rhae (M. Langton and Z. Ma Rhea, 2003). 
territories, and for the harvesting of wild food and animals, medicines, water, and other basic needs. Hunting, gathering and fishing continue to contribute a substantial part of the diet and basic needs for populations in rural and remote areas of Australia and among coastal groups in Asia that rely on artisanal fisheries (See K.Ruddle 1993a, 1993b, 1994; K.Ruddle,1992; K.Ruddle and R.Johannes 1990).

Indigenous societies based on sedentary and nomadic agricultural economies, pastoral and herding economies, hunting, fishing and gathering economies and other forms of economic organization support widely divergent symbolic and social exchange systems that redistribute material and non-material values, customary laws and traditions and property and land tenure systems. Religion plays a significant role in these societies and acts to regulate the use and management of resources and maintain systems of traditional knowledge, especially biodiversity-related knowledge. Darryl Posey observed that:

Agriculture, for example, can provide 'balance for well-being' through relationships not only among people, but also nature and deities. In this concept, the blessing of a new field represents not mere spectacle, but an inseparable part of life where the highest value is harmony with the Earth. Most traditions recognize linkages between health, diet, properties of different foods and medicinal plants, and horticultural/natural resource management practices - all within a highly articulated cosmological/social context. The plant, animal or crystal some ethno-pharmacologist or scientist wants to collect, may, in fact, encompass, contain, or actually be the manifestation of ancestral spirits-or even of the local healers' own progenitors. Local knowledge embraces information about location, movements, and other factors explaining spatial patterns and timing in the ecosystem, including sequences of events, cycles, and trends. Direct links with the land are fundamental and obligations to maintain those connections form the core of individual and group identity (2003: 125).

In relation to hunter-gather societies Western literature generally emphasizes 'the subsistence role rather than the productivity of hunting (the production of social cohesion, the communication with the mythic countryside, and the gathering of healthy foods for the human body)' (E.Povinelli 1993: 60). We agree with Povinelli's contention that 'hunting and gathering contributes to local cultural, economic, and sociological well-being' (1993: 62), and support for this can be found throughout the literature. We also agree with her in her contention that:

...discussions of the Fourth World have as yet failed to describe adequately the dense network of economic, political, and cultural motivations that account for indigenous practice (in particular indigenous struggles to produce economic and cultural well-being in the postcolonial nation) or to theorize the relationship between the productivity of indigenous practice and the production of cultural identity (1993: 24).

These points are well borne out in the findings of both Jon Altman $(1987,2003)$ and Povinelli (1993) just two of the anthropologists whose work has described the actual food and other production of such hunting and gathering economies in Australia. Altman (2003) and Povinelli (1993) argue that despite the impacts of modernisation, which has caused accelerated change across traditional societies and their different economic systems, hunting and gathering bush foods in northern Australia continue as socially integrated aspects of Aboriginal lifestyles. Based on her work in a northern Australian indigenous community, Povinelli (1993: 59-60) has documented for instance, that, 'at times of economic scarcity, bush foods provide an important supplement to people's diet'. Altman (2003: 71) compares his 1979-1980 fieldwork findings in a remote northern Australian Aboriginal community in the wet-dry tropic with those of 2002: 'In 1979-1980 I observed 90 animal species...regularly harvested and 80 plant species consumed while 56 plant species... were used in non-dietary ways, mainly in the manufacture of artefacts.' In 2003, Altman found that the harvesting practices were remarkably similar:

In ecological terms, ...there had been no decline in the common species generally harvested...Furthermore, information on harvesting levels and species stocks makes it clear that harvesting is within ecologically sustainable limits...this economy is structurally the same hybrid economy with customary (hunting), market (arts production and sale) and state (income support transfers) sectors in both periods (2003: 72). 
The diverse systems of food production among indigenous societies impact in various ways on the readiness of governments to institute protected areas and the legal nature of such protected areas with respect to the recognition of subsistence rights. The readiness of nation states to recognise the intertwined destinies of natural and cultural diversity in the areas where traditional societies continue economic subsistence practices and related knowledge systems is influenced at the highest political levels by environmental NGOs, whose understanding of these issues has often lagged behind the urgent demands of the indigenous and local peoples for protection of their traditional resource rights (See, for instance, H.Magome and J.Murombedzi 2003). While over the last decade environmental organisations have begun to champion the link between environmental protection and the 'protection' of indigenous peoples, some writers such as Mac Chapin (2004) argue that an apparent lack of success in this endeavour (ie. provision of funding to conservation projects that committed themselves as well to the plight of indigenous peoples) has led international environmental organisations to retract their support in practice, if not in their rhetoric. Similarly Langton (2003: 142) observes 'As well as the opposition by some governments seeking appropriate indigenous lands and resources, conservationist organizations resist compromise on land use issues because they believe that global biodiversity preservation goals take precedence over the needs of local people'. The implications of such attitudes are profound, given what often appear to be the seamless alliances forged between the rhetoric of ecological modernisation and the state. In this context, the rights of indigenous and local communities are, more often than not, limited by statutes and regulations because of the ideological stance that modern nation states hold towards these subsistence economic systems, holding them to be backward ways of life as against the belief in 'progressive' ways of life that the modern global economy is purported to offer (see M.Colchester 2004; T.M.Li 2003). Developments in the international arena of United Nations agencies and non-government organisations, including a system of reporting by United Nations Member States, result in further complications in the recognition of indigenous rights in this area. This is discussed in the following section.

\section{Emerging International and National Frameworks for the Development of Community-Oriented Protected Areas}

A number of global organisations - including the International Union for the Conservation of Nature (IUCN), United Nations Educational, Scientific and Cultural Organization (UNESCO), and the World Bank — are increasingly linking global sustainability to a greater awareness of Indigenous Knowledge (IK) and the rights and interests of indigenous peoples and local communities over the resources they manage are to some extent recognised by these international frameworks. ${ }^{4}$ For example, the preamble to the Convention on Biological Diversity (CBD) 'recognises the close and traditional dependence of many indigenous and local communities ... on biological resources, and the desirability of sharing equitably benefits arising from the use of traditional knowledge, innovations and practices relevant to the conservation of biological diversity and the sustainable use of its components'.

However, despite national reporting procedures and related mechanisms particularly concerned with the protection and maintenance of traditional biodiversity related knowledge under Article $8 \mathrm{j}$ of the $\mathrm{CBD}^{5}$ and despite the plethora of developments concerned with documenting and patenting of, for example, traditional biodiversity related knowledge, there is little consensus about whether, and if so how, indigenous knowledge and traditional biodiversity related knowledge should be protected.

Under Article 8 of the Convention, concerned with in situ conservation, the CBD Member states are obliged to, as far as possible and as appropriate, "(a) Establish a system of protected areas or areas where special measures need to be taken to conserve biological diversity." Article 8j of the Convention further obliges Parties as follows:

Subject to its national legislation, respect, preserve and maintain knowledge, innovations and practices of indigenous peoples and local communities embodying traditional lifestyles relevant for the conservation and sustainable use of biological diversity and promote their wider application with the approval and involvement of the holders of such knowledge, innovations and practices

\footnotetext{
$4 \quad$ For example the Convention on Biological Diversity (CBD) and frameworks emanating from the World Intellectual Property Organization (WIPO), the Food and Agriculture Organization (FAO), the World Trade Organization, UNCTAD, the World Health Organization (WHO), and UNESCO.

M. Langton and Z. Ma Rhea (2003); see also Ma Rhea (2004).
} 
and encourage the equitable sharing of the benefits arising from the utilization of such knowledge, innovations and practices. ${ }^{6}$

Most countries have developed National Biodiversity Strategy and Action Plans (NBSAPs) to strengthen their capacity to respond to their obligations under the CBD. These NBSAPs contain elements that acknowledge, in various ways, indigenous peoples and local communities and in situ conservation measures that involve these peoples who retain traditional or indigenous knowledge systems. These acknowledgements are not without contradiction and represent the diversity of opinion and policy on how to position indigenous peoples and local communities in both the nation state and within the global modern market economy whilst at the same time recognising that for many economically developing nations that the majority of their people survive outside cities, within a subsistence economy that relies heavily on traditional food production knowledge.

For example, most economically developing nations of the Asian region do not have the capacity for all of the people who live within their borders to fully enter the market economy, and that without attention paid to the protection and preservation of the lands and waters of local communities and indigenous peoples, these nations would be unable to feed their populations. This critical fact has given impetus to serious consideration of the development of community-oriented protected areas across the region to ensure that national resources development does not result in massive food shortages and increased migration to already overcrowded urban centres.

Some nation states, in acknowledgement of their agreement to the principles of the CBD, are seeking ways to conserve rich biospheres whilst balancing a need to ensure that traditional communities can continue to sustain themselves. Given that in most regions of the globe significant numbers of people rely on access to their traditional land and sea resources for survival, it is in the interests of nations to engage indigenous peoples and local communities in the task of protecting the biological diversity in their environment. As Arturo Escobar (1998: 56) argues, however, the biodiversity network constituted by global and national 'institutional apparatuses' promulgates strategies and programs, and creates knowledge and power based on a techno-scientific idea of biodiversity. While Article 8j functions to give some attention to local knowledges, Escobar argues that '... this attention is insufficient and often misguided to the extent that local knowledge is rarely understood in its own terms or it is refunctionalised to serve the interest of Western-style conservation' (1998: 61).

Escobar (1998: 59) suggests that the plans and strategies put forward by nation states for the conservation of biological diversity 'can be analysed ethnographically as instances of the organisation of knowledge and power'. Likewise Agrawal (1995) suggests the critical difference between indigenous and Western knowledge is one of power and the ability to legitimate the social construction of particular forms of knowledge.

The ability of the nation state to control the organisation of knowledge and power is increasingly challenged by 'appearance of new social actors, including progressive NGOs in many countries and local social movements engaged in the redefinition of cultural and ethnic identities' (A.Escobar 1998: 56). These new social actors inscribe themselves within the knowledge-power network of the techno-scientific biodiversity discourse, often acting as cultural 'brokers' conversing across indigenous and Western worlds, and alternatively resist, subvert or recreate it to serve other ends. This 'opens up a space for the construction of culturally based forms of development [where what is at issue] is the defense of an entire life project, not only of “resources” or biodiversity” (A.Escobar 1998: 61, see also M.Blaser 2003). In addition, there are numerous foreign aid donors that attempt in various ways to mobilise traditional biodiversity knowledge of local peoples, when that knowledge is seen to conserve the local environment, although as noted above this trend is waning in some sectors (Chapin 2004).

Whether traditional biodiversity related knowledge ${ }^{7}$ is protected as a property right, a resource right, or under benefit-sharing arrangements is a matter of critical debate, and greatly depends on the nation state solution imposed on indigenous and local groups. In relation to protected areas, Ashish Kothari notes that the signatory countries of the CBD have agreed under the terms of a Programme of Work for Protected Areas:

...to recognising the rights of local communities to participate in planning and management of protected areas, to provide communities full benefits from such areas, to respect communities traditional rights to territories and resources, and

\footnotetext{
6 Convention on Biological Diversity Article 8. In-situ Conservation, $<$ http://www.biodiv.org/convention/articles.asp?lg=0\&a=cbd-08> (27 January 2004). As defined under article 8j of the Convention of Biological Diversity.
} 
to seek prior consent before considering any resettlement of communities from within protected areas (2004: n.p.).

Kothari points out, however, that despite the rhetoric of international conservation covenants, nation-state signatories often contradict them in practice. In late 2004, because of actions which are both contrary to trends elsewhere in the world and to its own obligations under the CBD, India faced a situation where approximately four million people were threatened with 'displacement and dispossession by a series of Central Government and Supreme Court orders on wildlife conservation'. Yet it was only in February 2004 that the Indian Government had committed itself to 'an ambitious target under the Convention of Biological Diversity (CBD): moving towards full participation of Adivasi and other local communities in the management of wildlife conservation, and in receiving benefits from such conservation, by 2008' (A.Kothari 2004: n.p.).

This is not to say however, that indigenous peoples are not at times able to invoke the rhetoric of international covenants to further their own aspirations. In his monograph on indigenous internationalism, which he theories elsewhere (R.Niezen 2004) as a process of 'globalization from below', Ronald Niezen (2003) writes of the ways in which the United Nations has become a focal point for an emergent Indigenism, a movement grounded in international networks. He writes:

...the development of an international movement of indigenous peoples in recent decades reflects a changing alignment of political advocacy and shows some indigenous leaders to be, despite their limited power and resources, among the most effective political strategists in the contemporary and international scenes. (R.Niezen 2003: 16)

Whether this advocacy is carried out in pursuit of the recognition of indigenous knowledge or in relation to other issues of importance to indigenous people, Niezen (2003) signals a central paradox in this emergent Indigenism: the clearest expression of human diversity is found in the universality of the category 'indigenous peoples'. It is then, following Tsing (2005), an 'engaged universal' which brings together cultural particularism and distinct collective rights alongside human rights universalisms and the laws of nation states themselves. Despite this paradox, it is a movement which offers indigenous peoples a wide range of safeguards and rights, including the possibility of achieving a degree of control over natural resources.

\section{Territorial Rights and Interests of Indigenous Peoples and Local Communities}

Of central importance in debates about the ongoing existence of indigenous peoples and local communities is the preservation of the territorial base of these peoples. Loss of territory, whether through expulsion of populations or destruction of territorial integrity through over-development, gazetting of protected areas, and other imposed land tenure arrangements, all impact severely on indigenous peoples and local communities because loss of territory deprives them of their homes and traditional livelihoods. Examples of these impacts that pose risks to the retention of biodiversity related knowledge are numerous throughout the literature. Further, loss of territory, expulsion and inadequate land tenure arrangements also impact, usually detrimentally, on biodiversity and the capacity of the local populations to sustain their traditional subsistence economies, knowledge of their natural environments and resource management practices. In Southeast Asia, for example, forestry and agroforestry operations impact on the territories of local communities and indigenous peoples severely, most importantly by diminishing their land base and their access to land and natural resources (cf. N.Peluso 1992, 1993, 1995; T.M.Li 2003; A.L.Tsing 2005).

In many areas, indigenous peoples and local communities have started to address conflict over resources themselves. For instance, communities are claiming their rights over their traditional lands and resources, be it individual and collective cultivated plots, fallow land, common forests, watershed and wetland areas, fishing grounds, all of which are inextricably linked to the physical, cultural and spiritual lives of these people. At the same time, 'Traditional and indigenous knowledge systems have also slowly been increasingly gaining recognition as providers of knowledge relevant to sustainable use' (M.Ferrari n.d).

However, while there is increasing recognition of the important role that indigenous peoples and local communities could, and should, play in sustainable biodiversity management, very few governments are ready to allow the development of appropriate policy, legal and institutional reforms necessary to delegate power to local communities and indigenous peoples 
concerning access to, and control over natural resources. Rather than recognising their traditional rights to land and resources, national governments tend to develop measures for the protection of traditional and indigenous biodiversity related knowledge and resource management systems for the primary purpose of commercialising and commodifying particular aspects of traditional knowledge and related natural resources (D.Posey 2003). If the potential for commercialisation becomes the key criteria for promoting, protecting and facilitating the use of traditional and indigenous knowledges, then the aspects of these knowledge systems of, for example, natural resource management that are not amenable to commodification and commercialisation will be placed in jeopardy, not least because sui generis protective measures will not be developed or extended to them. As Escobar writes, there is a danger that 'conservation strategies will amount to the merchandising of biodiversity' (1998: 75).

\section{The Recognition of Indigenous Populations}

In parallel with the critical need to halt and reverse the loss of the territories of indigenous peoples and local communities, the existence of these peoples needs also to be acknowledged and protected within national constitutions and legislation. Constitutional and legislative protection of the existence and rights of indigenous peoples and local communities is critical to the capacity of nations to formally recognise them as ethnically or historically distinctive holders of traditional territories, and unique biodiversity related knowledge. The CBD, like other international frameworks, affirms national sovereignty over lands and biological resources and does not recognise sub-rights or a priori rights against the nation state. Their mandate relies on the nation state signatories to undertake such processes of constitutional recognition of indigenous peoples and local communities as would enable enactment of domestic laws for their benefit. Constitutional acknowledgement of the existence of indigenous peoples and local communities, in many cases, informs the legislative protection of indigenous peoples' and local communities' rights. However, even without a constitutional mandate, some nations have enacted legislation that recognises the unique position of indigenous peoples and local communities vis-à-vis the nation state.

The question of who exactly are indigenous people and how their rights and interests may differ from other local populations is in many contexts a vexatious issue. Niezen (2003) argues that while there are various contested definitions of Indigeneity, the concept is historically contingent rather than categorical. ${ }^{8}$ The process of definition is a highly politicized act and one of the more widely accepted definitions is provided by Jose Martinez Cobo:

Indigenous communities, peoples and nations are those which, having a historical continuity with pre-invasion and post-colonial societies that developed on their territories, consider themselves distinct from other sectors of the societies now prevailing in those territories, or parts of them. They form at present non-dominant sectors of society and are determined to preserve, develop and transmit to future generations their ancestral territories, and ethnic identity, as the basis of their continued existences as peoples, in accordance with their own cultural patterns, social institutions and legal systems (1987: 48).

This definition, however, cannot apply to all situations where people may identify as indigenous, for example in the complex patterns of displacements and movements of people in south-east Asia (R.Niezen 2003: 20). And as Niezen (2003: 18) notes, the challenge of definition grows as more people claiming indigenous status emerge from Asia and Africa with their different historical experiences of colonialism and de-colonisation. In this context he asserts that debates over the problem of definition of Indigeneity are more interesting than the definition itself.

By example, in Malaysia, a state with multiple ethnic, indigenous and religious subgroups, the differential recognition of local groups in the Constitution has at times frustrated attempts to coordinate a nationally consistent system. Each of Malaysia's thirteen states has its own legislature. While Malaysia's constitutional system ensures local governance for local communities, the fragmentation of legal control in relation to traditional knowledge has resulted in unequal distribution of rights for indigenous peoples and local communities. State lawmaking powers in respect of traditional knowledge, local land management and intellectual property are scattered between the various (national, state and municipal) competencies. The States of Sabah and Sarawak have a special constitutional status which guarantees them, at least in superficial terms, special rights; and, as a result, Sabah and Sarawak are excluded from national plans for land use, local government and development (V.King 1995: 294).

\footnotetext{
${ }^{8}$ It is an identity developed largely in relation to a shared history of oppression (Niezen 2003).
} 
As Kirk Endicott (2003: 145-146) points out, in postcolonial Malaysia, pro-indigenous government policies and programs are intended to benefit only some segments of the nations officially recognised 'indigenous' population (as against the also numerically large immigrant Chinese and Indian populations). Despite the fact that the 'Malays', the nation's largest and an officially recognised 'indigenous' ethnic group began to settle the Malay peninsula and Borneo from around $2000 \mathrm{BC}$, the 'true' indigenes are the politically marginalised ethnic groups the Orang Asli ('Original People'), and their neighbours the Sabah and Sarawak natives, who have inhabited the area prior to the arrival of the ethnically diverse 'Malays'. The government's attempts to unify these ethnically diverse groups under a nationalist umbrella are pursued through the creation of a national culture based on an 'indigenous' Malay culture, language and educational system. Through an ethnically based policy of state sanctioned 'indigenisation', the politically marginalised indigenous groups, the natives of Malaysian Borneo and the Orang Asli, are treated as 'anomalous afterthoughts' and are, in practice, actively discriminated against for standing in the way of nation building and progress (K.Endicott 2003:146).

In neighbouring Indonesia, the Constitution recognises indigenous institutions, as well as organizations, mechanisms, laws, rights and obligations within the institutional system of the indigenous peoples. However, like Malaysia, the multifarious system of government in Indonesia has led to tensions between local and centralised governmental institutions. As Indonesian indigenous territories are considered special territories, the Indonesian Constitution affords special treatment (again not always beneficial) for indigenous groups whose interests differ from those of the mainstream. As Colchester explains, 'In Indonesia the government policy recognises a class of peoples, officially referred to as 'suku suku terasing' or 'masyarakat terasing' (isolated and alien tribes/peoples), as requiring special attention in development', Government estimates put their numbers at around 1.3 million (M.Colchester, 1986). However, a civil society movement of self-identified 'indigenous Peoples' formed in 1999, who refer to themselves as 'masyarakat adat' (peoples governed by custom). As Ferrari explains, the 1999 General Statement from the First Congress of the Alliance of Archipelagic Indigenous Peoples (AMAN), stated that the indigenous peoples are 'communities who for generations base their lives on origin in a certain customary area, who have sovereignty over land and resources, whose socio-cultural lives are governed by customary laws and institutions, which regulate the communities' lives' (from Sombolinggi questionnaire 2002 cited in M.Ferrari n.d, see also T.M.Li 2003). This definition embraces a far wider set of peoples, who are 'guesstimated' to number as many as 65 million (M.Colchester 2000). According to Tsing (2005) the AMAN movement emerged slowly out of a loose and, at times, contradictory amalgam of Indonesian activists and local peoples, often pursuing outcomes and policies under the rubric of community-based natural resource management. Under the grip of then President Suharto's New Order Government, political constraints had a particular role in shaping these coalitions. Tsing explains:

...in the 1980s and 1990s, Indonesian activists built something rather exciting under the banner of environmentalism. This was a time of state repression. The environment was one of the few topics open for critical discussion. Environmentalism cleared the way for other movements in the 1990s, blossoming into human rights and labor concerns, as they became possible (2005 216).

During the turbulence of the late 1990s Indonesian Reformasi and political upheavals, one of those movements which benefited from, and arguably itself played a key role in fostering the democracy seeking demands of other Indonesian activist groups (J.Goodman 1999), was the long-suffering indigenous population of the tiny half-island of Timor-Leste.

In 2002, following an overwhelming vote for independence in the 1999 United Nations sponsored referendum, Timor Leste became the world's newest nation (J.Dunn 2003). The Government of Timor Leste is now engaged in the task of confirming the state as a 'geo-body' (W.Thongchai 1994 cited in B.Anderson 2003: 165). According to Benedict Anderson (2003), in an article written prior to the Independence of Timor Leste, those peoples that pursue the process of creating patriotic nationalist movements that then seek nationhood under a banner of what he terms 'aggregated nativeness', have mimicked the strategies of late colonial-era nationalist movements. Here he is referring to places such as Indonesia, where in the preIndependence era anti-colonial nationalists initially rejected discussion of 'minorities' as an imperialist tactic of divide-and-rule. Theirs was a strategy based on the coalitional 're-creation of a "people"'; the 'transformation of consciousness and the past'; and 'profoundly homogenising instincts' (B.Anderson 2003: 166). Ironically for Timor Leste the 'aggregated nativeness' strategy of nationalism as a means of cultural survival has been successfully pursued at the same time as the sanctity of the nation-state is under threat in other, older states. As 
Anderson asserts 'for the culture of nationalism ... survival cannot be enough' (2003: 184) and as with all other nationalisms, Timor Leste's nationalist agenda is engaged in the search for futures. In such contexts, what, asks Anderson, will survive this 'new "national" cultural survival?' (2003: 166). Will the process include the active involvement of indigenous Timorese traditions, practices and priorities in the governance of the nation (B.Kehi 2005)?

As it attempts to fashion itself as a modern nation-state in the aftermath of the destruction exacted by Indonesian troops as they withdrew from the territory in 1999, Timor Leste faces many complex social and economic issues (J.Hunt 2004; J.Fox and D.B.Soares 2000). In the struggle to rebuild Timor Leste's economy, infrastructure and institutions, the issue of power-sharing and centralisation is increasingly contentious (B.Kehi 2005). Yet in order to produce its national development plans the Government has consulted widely, and in relation to resource management regimes it has recognised the need to involve local communities in environmental governance in order to achieve food security and sustainable livelihoods and to protect and encourage the sustainable use of forests and traditional medicinal plants. ${ }^{9}$ The Government also has plans to develop programmes for biodiversity protection and conservation over the next five years (Timor-Leste National Planning Commission 2002: 1517). It is unclear, however, what legal and administrative measures will be adopted to support and provide protection for the myriad of culturally distinct local communities - entities with their own indigenous governance structures and biodiversity related knowledge systems.

In this context, the development of land tenure and resource management policies and the implementation of new regimes to enact these policies are critical issues for the new nationstate to address (D.Fitzpatrick 2002, 2005; A.McWilliam 2002, 2003; S.Ospina and T.Hohe 2002). Timor Leste is a country with extensive areas of customary land holdings and a complex postcolonial land rights environment. The Government is currently devising legal and bureaucratic models of land titling and resource use and it is at this stage unclear what recognition will be provided to customary and local structures of owning and managing land and resources. While customary land tenure is not explicitly recognized under the Constitution, it is clearly stated that all natural resources are owned by the State. The Directorate of Forestry in Timor Leste is currently planning for and developing a system of national parks across the territory. However, in at least one of these instance concerns have already been raised about the inadequate involvement and lack of recognition of the customary rights and interests of local landowning communities in relation to the park creation process (A.McWilliam forthcoming).

As a result of their European genealogies and settler state histories, Australia and New Zealand are a special case in the Asian region. Settler peoples in Australia do not claim to be holders of traditional and indigenous knowledge systems, and therefore the Australian response to international covenants on the recognition of indigenous knowledge presents a distinctly different situation from that found elsewhere in the Asian region where national majorities are able to assert at least some legitimacy as traditional or indigenous knowledge holders (see R.Niezen 2003). However, in Australia, the rights of indigenous peoples are not recognised in the Constitution, and moreover, the High Court has found that their interests may be dealt with to their detriment, although some rights are protected by law (G.Nettheim et al 2003). While about 18 per cent of Australia's land mass is held under a variety of statutory titles by Aboriginal and Torres Strait Islander peoples, there are other areas, especially unallocated Crown land, where native title may be found by the common law to have survived if Aboriginal groups can prove to the Courts that they retain a special connection through descent and occupation (see M.Tehan 2003). The 1996 National Strategy for the Conservation of Australia's Biological Diversity recommends a framework within which governments, industry, community groups and individual land owners work cooperatively to 'bridge the gap between current efforts and the effective identification, conservation and management of Australia's biological diversity'. In the light of this strategy and their significant land holdings, indigenous people, government and others are now engaged in defining emerging resource rights (see below, and ATSIC and Lingiari Foundation Partnership 2002; J.Altman 2002; M.Langton 2003; M.Langton and L.Palmer 2003).

In New Zealand, a country that has no formal constitution, indigenous rights and authority to govern, manage and use their traditional territories and resources are recognised both in the common law doctrine of Aboriginal title and in the Treaty of Waitangi signed in 1840 between the Maori chiefs and the British colonial government. The Treaty of Waitangi 'is recognised as the founding document of New Zealand and resides in the constitutional field of its system of government' (S.Dorsett and L.Godden 1998: 32). Garth Nettheim et al. report that:

9 Although it is not clear what recognition and protection will be provided for Indigenous intellectual property in this regard. 
...the relationship between the European settlers and indigenous New Zealanders (and the consequential acknowledgement of Maori rights by Pakeha [white settler] governments) has moved in stages from rough equality to denial and assimilation to a recognition of the special place of Maori culture in New Zealand and limited rights to self-determination and management of land and resources (2002: 119).

As with Australia, apart for lands owned under some form of indigenous title, Maori have limited 'power to manage and conserve their environment' (G.Nettheim et al 2002: 147). However, New Zealand's Biodiversity Strategy has as the second of its four goals the active protection of Maori interests in indigenous biodiversity. ${ }^{10}$ The strategy provides for:

...the active protection of tangata whenua [people of the land] interests in biodiversity, reflecting the principles of kawanatanga [governorship], rangatiratanga [chieftanship], kaitiakitanga [guardianship], and the Crown's duty of active protection of Maori interests as laid down in the Treaty. It also endorses the creation and strengthening of partnerships between government agencies and iwi [tribe] and hapu [sub-tribe] in the shared management of indigenous biodiversity. This reflects the Treaty principle of partnership (New Zealand Biodiversity Strategy, n.d.).

On the basis of the particular forms of constitutional and legislative recognition that they provide for indigenous and local communities, nation states make decisions and assume administrative responsibility for operationalising the rights and interests of local communities and indigenous peoples. Along with their own particular political and legal imperatives, some of these decisions are driven by the need to ensure the subsistence economy of the local area and other decisions are being formulated through the need to capitalise on traditional knowledges for the creation of national economic benefit within the global market economy (Posey 2003). For both of these purposes, there is an emerging consensus on the need for protected areas for indigenous peoples and local communities although the form they are taking varies considerably, as discussed next.

\section{The Emergence of Community-oriented Protected Areas}

The Western concept of protected areas, dating back to 1872 when the first modern protected area was established in the USA, usually focuses on spectacular biological or physiographic features for the limited purpose of conservation. Yellowstone National Park in the United States, established in 1872 following the forced removal of indigenous Indians, remains the national park model followed by many countries (H.Magome and J.Murombedzi 2003: 111). Likewise the 'language of biodiversity enshrined in the Convention on Biological Diversity has come to drive a program of action based upon the identification and protection of critically biodiverse areas - a 'protected area' strategy - which is based largely on a model of national parks and wilderness reserves historically found in the United States' (W.Adams and M.Mulligan 2003: 10).

In the past, this has resulted in a diminished role for dependent indigenous peoples and local communities under new management regimes. Such approaches to protected areas management have excluded or marginalised the land management practices and knowledge of indigenous peoples and local communities and adversely affected the pursuit of sustainable economic and cultural livelihoods on their ancestral lands. ${ }^{11}$ For example, the Moken people in Southern Thailand were effectively excluded from participation in land management when their traditional lands and waters were declared 'protected areas' (UNESCO/CSI 2000). Kothari, writing about conservation in South Asia writes:

10 For further details on the status and trends regarding the knowledge, innovations and practices of indigenous and local communities relevant to the conservation and sustainable use of biodiversity in New Zealand, see Solomon (2003).

The restitution of previous 'protected areas' in order that local communities and indigenous peoples might again have access to their traditional lands and resources was a focal point of discussion at the conference on 'indigenous Peoples and Protected Areas in South and Southeast Asia - from Theory to Practice' held in Sabah, Malaysia in December 1998. Conference representatives from indigenous peoples and local communities called for an accounting of past injustices and the restitution of ancestral territories alienated because of the creation of ‘conservation focused’ protected areas (Tauli-Corpuz 1999, in Ferrari n.d.). 
Wildlife policies and laws have gone wrong in the past in curtailing not only destructive resource uses but also sustainable ones; in converting legitimate users into criminals; in forcing people to 'steal', bribe, collude with poachers or in other ways undermine conservation efforts; and in alienating people (2003: 61).

Maurizio Ferrari provides an insightful account of how indigenous peoples and local communities in Southeast Asia have been disenfranchised of their traditional governance and management role in relation to natural resources:

The vast majority of natural resources in most Southeast Asian countries are government-controlled. Starting with the introduction of Western land administration systems during colonial time, virtually any land that does not belong to individuals automatically belongs to the government, apart from limited examples of common customary land rights. Through the introduction of the modern state during the past two centuries, most terrestrial as well as aquatic ecosystems that were traditionally managed by local communities according to time-tested indigenous systems have come under the ownership of government agencies, with the resulting de jure alienation and marginalisation of the local communities. The degree to which indigenous peoples and local communities can exercise governance of their resources is subject to government priorities, business sector demands for these resources, and the strength of local organisations. The issue of indigenous and local governance and management of natural resources, and hence management of biodiversity through traditional biodiversity related knowledge systems, is a highly political issue (n.d.).

Indigenous and local groups face threats from the nation state in this regard, and, without recourse to legal protection, they may be relatively powerless when the competitors for their natural resources are business interests with influence at the government level. This is particularly the case in those nations where the expanding forestry industries and other economic activities contribute large amounts of export dollars to both national economies and corrupt regimes (cf. N.Peluso 1992; T.M.Li 1999; A.L.Tsing 2005).

Despite formidable obstacles, powerful vested interests and approaches to protected area management which have been narrowly conceived, centralised and elitist, the way that government sponsored conservation is practiced in many parts of the world is changing, albeit slowly and at times in contradictory directions (see above). The move is generally towards a model of decentralised, participatory protected areas management (A.Phillips 2003). In some cases, the development of protected areas, supported by legislation, strategic plans, and incentive measures in addition to capacity building initiatives involving the local community, have provided measures to preserve and maintain traditional knowledge. Global trends in protected area governance have seen a shift towards recognising and supporting communityoriented protected area management (M.Colchester 2004; H.Jaireth and D.Smyth 2003, see also J.Beltran 2000). In this context, the establishment or re-negotiation of 'protected areas' models as a key mechanism for protecting the rights and interests of indigenous peoples and local communities within the nation state has emerged over the last several decades (J.Igoe 2004, see also P.Brosius 2004).

Ferrari observes that since the 1980s, and increasingly during the past decade, some governments started to admit that they have not succeeded in sustainably managing natural resources (especially forests and coastal ecosystems) and that local communities and indigenous peoples need to become more involved in biodiversity management as they are the ones living closest to the resources that are supposed to be sustainably managed. The increasing scale of conservation initiatives undertaken by indigenous peoples and local communities have also contributed to the retention of traditional biodiversity related knowledge. Ferrari says:

In several Southeast Asian countries, indigenous peoples and local communities have been taking active initiative in conserving and sustainably managing biodiversity, sometimes on their own but often with the support of NGOs or as joint management with government departments, despite the lack of supporting legal instruments. There is a recent increasing trend in community conservation initiatives (the IUCN has recently coined the term 'community-conserved areas') and in community involvement in conservation initiatives initiated by NGOs or government agencies (n.d.). 
The shift from a 'fortress conservation' framework to a community-oriented protected areas approach has emerged alongside international trends seeking to combine conservation and community development - the notion of community-based conservation (A.Phillips 2003). This has paralleled shifts which have occurred in the discipline of applied ecology away from reductionism to a systems view of the ecosystem, towards an inclusion of humans in the ecosystem, and away from expert-based approaches to participatory approaches to ecosystem management (F.Berkes 2004).

There are criticisms of the community-based conservation approach. Fikret Berkes, along with many others, notes that 'the term community hides a great deal of complexity' (2004:623). Rather than being treated as isolated and static entities, Berkes argues that communities are better thought of as 'multi-dimensional, cross-scale, social-political units or networks changing through time' (2004: 623). More trenchantly others have noted that uncritically linking together conservation and development objectives is often counterproductive for both objectives (K.Redford and S.Sanderson 2000; see also W.Adams et al 2004; A.Agrawal and K.Redford 2005; A.Agrawal and J.Ribot 2000). We argue here, that despite the legitimate concerns of these authors, an equally critical gaze needs to be cast over the reasons for the success or otherwise of project outcomes which arise from community-based conservation based on community-oriented participation in externally controlled conservation projects/programs and the outcomes of those conservation-oriented projects/programs which are themselves community driven and controlled. The critical objects of analysis here are the environmental governance frameworks employed and the location of authority in decisionmaking and project responsibility.

In what follows, we examine developments in protected areas management in Australia, specifically the IPA program, and the ways in which such programs are prising open a space for the mainstream recognition of indigenous peoples' environmental governance priorities and decision making processes. In this analysis, the concept of 'community', like the concepts of 'biodiversity' and 'Indigeneity' in the previous discussion, is treated as an 'engaged universal' (A.L.Tsing 2005), a discursive frame that enables the collaboration of diverse actors and players under the rhetoric of community-based conservation. While the networks and overlapping agendas of such collaborations are the subject of power and knowledge struggles, here we are interested in their ongoing and often contradictory, unstable and even fleeting, material effects (A.L.Tsing 2005). As Tsing writes, despite the 'standard lines' pitched to funding agencies to enable such collaborations 'when the grantees go home', those involved in the projects-individuals, communities, their advocates and critics - 'must work these lines into the matrix of possibilities offered by their practical situations' (A.L.Tsing 2005: 264). Tsing (2005: 5-6) deploys the 'metaphorical image of friction' in order to remind us 'that heterogeneous and unequal encounters can lead to new arrangements of culture and power. ... [that] The effects of encounters across difference can be compromising or empowering'. In these contexts, she writes:

"Communities" are constituted in relation to other kinds of scale-making projects, including bureaucracies, nations and international bodies of power and expertise. Community-making projects may or may not empower local peoples; it all depends on just how this relation is organised: Who benefits? (2005: 264).

It is our contention that the IPA program does offer indigenous peoples involved in the program a way to benefit from 'engaged universals'. The internal complexities of how this endeavour plays out at the level of individual 'communities' is, however, beyond the scope of this paper.

\section{Protected Areas in Australia}

Indigenous peoples living in rural and remote areas of Australia, like their counterparts elsewhere, are concerned to promote and maintain their active involvement in the pursuit of environmental security and sustainable economic livelihoods on their ancestral lands.

In the National Strategy for the Conservation of Australia's Biodiversity, the Australian government has committed to enhancing the effective participation of indigenous Australians in the management and protection of biological diversity. There are various legal and practical reasons for the Australian government to incorporate indigenous customary interests into the broader Australian project of land, sea and resource conservation. Land and water subject to indigenous ownership and governance constitutes a significant and substantial 
proportion of the Australian continent, particularly in northern and central Australia. ${ }^{12}$ Since the High Courts finding in the landmark Mabo ${ }^{13}$ judgement and the codification of the Native Title Act 1993, native title rights to land, sea and resources are now recognised in Australia's legislative landscape. ${ }^{14}$ In 1999 some customary rights in fauna were also found to exist as a form of native title by the High Court of Australia. ${ }^{15}$ Furthermore, indigenous ownership and input to management of land will increase as statutory and indigenous corporations acquire more land for constituent groups through commercial dealings, as indigenous groups exercise their statutory and common law native title rights, and acquire access to, and control of, national parks and state forests under management cultural heritage agreements (Hassall and Associates 2003: 100). ${ }^{16}$

Despite the influence of the North American model on the development of its national parks, Australia has, in relation to certain key national parks, taken a lead role in the development of joint management agreements with indigenous groups. Nevertheless, even in jointly managed parks where indigenous people maintain ownership and varied degrees of control over their estates, tensions still arise between western and indigenous ways of practising land management. This is the case, for example, in both the Kakadu and Uluru-Kata Tjuta national parks which are jointly managed by a lease agreement between traditional Aboriginal land owners and the Federal government (see for example D.Lawrence 2000; L.Palmer 2004a, 2004b; T.Power 2003).

The Federal government's Indigenous Protected Area program was established in 1996 as a part of the Federal government's push to establish a National Reserve System (NRS). According to the national strategy the aim of the NRS was to 'establish and manage a comprehensive, adequate and representative system of protected areas covering Australia's biological diversity' (Commonwealth of Australia 1996: 9). It aimed to address gaps in the kinds of ecosystems under protected area management and divided the continent in 85 regions under a process called the Interim Biogeographic Regionalisation of Australia (IBRA) which was based on factors associated with climate, lithology, geology, landforms and vegetation. The IBRA provides the bioregional planning framework for developing the NRS and the data generated on existing protected areas and gaps in the protected area estate is used to inform future land acquisitions. The usual method of adding to nation's conservation estate is through the government purchase of land which is then set aside as parks and reserves.

12 In Australia's Northern Territory, for example, Aboriginal people own over 50 percent of the land mass and over 80 percent of the coastline. The lands and waters that constitute most of this area are not subject to high density settlement, degradation of natural values by industries such as agriculture, forestry, fishing, pastoralism and tourism, and are high integrity areas both in terms of so called natural and cultural values. Much of the lands and waters within the indigenous domain remain subject to indigenous management systems (see M. Langton 2003). Indigenous people are also an increasing proportion of rural and remote communities, with a birth rate higher than the rest of the Australian population.

$13 \quad$ Mabo and Others v. Queensland (No.2) (1992) 175 CLR 1

14 Under Australian law, native title may be recognised in areas of unalienated Crown land where Indigenous people continue to follow their traditional laws and customs and have maintained an unbroken link with their traditional country. These criteria pose sever obstacles for those indigenous Australians who have in the past been forcibly removed from their lands (see M.Tehan 2003).

In an appeal by Aboriginal activist Marandoo Yanner in relation to his charge under Queensland's Fauna Conservation Act 1974 for hunting crocodiles; see Yanner v Eaton [1999] HCA 53.

For example, ongoing commercial purchases by the indigenous Land Corporation and Aboriginal Land Councils. The Australian Indigenous Land Corporation (ILC) which operates under the Native Title Act 1993 to fund land acquisition and land management activities, has produced the National Indigenous Land Strategy 2001-2006 in relation to indigenous land and sea management. In 'land management' the ILC's mandate is to assist indigenous people to 'manage their lands in a sustainable way providing them with cultural, social, environmental and economic benefits' (ILC 2003a:3). The ILC recognizes the centrality of the indigenous relationship to land as a defining principle in setting priorities in its land acquisition and management functions. The ILC may undertake land management activities on all indigenousheld land, including lands it has assisted indigenous peoples to acquire. For land to be classified as 'Indigenous-held land', it must be held by an 'Indigenous organization' as defined by the Aboriginal and Torres Strait Islander Commission Act 1989. Land ownership, and support for the management of that land, is thus legitimized by the administrative category of an 'Indigenous organization'. These benefits include the employment/training of indigenous people and indigenous business development (ILC 1997, 2003a, 2003b, NNTT 2003). 
However, as the IBRA planning framework was drawn up, the government was also forced to recognise the fact that in some instances, such as under the provisions of the Aboriginal Land Rights Act 1976 (ALRA) in the Northern Territory, Aboriginal people owned whole bioregions. Moreover the existence of native title, native title claims and the future act regime built in the Native Title Act 1993 were all issues that would impinge upon the government's appropriation of land for the national reserve system. At the same time the Indigenous Land Corporation, a statutory body set up met the needs of those indigenous groups for whom success with native title claims would be elusive, were also increasing the size of the indigenous estate through sizeable land purchases.

Prior to the establishment of the NRS, several Federal inquiries and reviews in early 1990s had highlighted the shortcomings in the recognition of indigenous peoples' interests in national park management across Australia (D.Smyth and J.Sutherland 1996: 96-97). At the same time there were increasing interest and initiatives by indigenous landholders to re-establish their land management traditions and cooperate with government conservation agencies to achieve there aspirations (D.Smyth and J.Sutherland 1996: 96-97). These initiatives were complemented at the international level by a new IUCN system of protected area categories which substantially recognized 'the rights and interests of indigenous people to own, manage and sustainably use areas of land and sea of high conservation value' (D.Smyth and J.Sutherland 1996: 96-97).

These new categories allowed for the establishment of protected areas which linked land and associated cultural values managed through legal or other effective means. It was a situation which created possibilities to enable indigenous land owners to manage protected areas on parity with the mainstream protected area estate. These combined initiatives resulted in the Federal conservation agency conducting a consultation process with indigenous organisations and state conservation agencies to discuss the establishment of what would become the Indigenous Protected Areas (IPA) program (D.Smyth 1995).

However, when indigenous groups and their representative bodies came together at two national workshops and expressed interest in the IPA idea as it could be applied to land owned by indigenous peoples, this interest was subject to a number of conditions:

- There would no loss of control over land by indigenous people. There was concern that government would try to take over the management of IPA land.

- That land owners make the decisions and the plan of management on their own terms.

- That the role of government would remain one of a 'good neighbour' providing advice and technical support on a needs basis on matters relating to issues such as weeds, feral animal management, and tourism infrastructure.

- That the commitment by government for the IPA program would be long term.

- That the government addresses, as an issue of equity, Aboriginal involvement in protected area management for those groups who have no land base a result of dispossession (pers. comm. S.Szabo 2002).

Following these negotiations the Federal Government proceeded with the establishment of an IPA program with two components: first, the development and declaration of IPAs on indigenous owned land where land owners manage the land as independent bodies, and second, a program to assist and support indigenous people to negotiate a land management role in existing government owned national parks and reserves with state agencies through some type of co-management arrangement.

The IPA program, which is supported by the Federal Government's Natural Heritage Trust (NHT), began in 1996 with an undertaking to develop twelve pilot projects situated in diverse locations including high density settled areas and remote areas. Some were IPA scoping projects and others were investigating co-management initiatives. The first IPA to be declared was Nantawarrina near the Flinders Ranges in South Australia in 1998. Since this time a further 18 IPAs have been declared, 11 others have been funded to pursue co-management arrangements in government-owned protected areas, and fourteen more have received interim funding to investigate the possibility of establishing an IPA (see Figure 1). IPA agreements are voluntary and are made between the Policy and Coordination section of the Federal Department of Environment and Heritage and indigenous communities, Land Councils and other indigenous bodies. They take the form of contractual one year Financial Assistance Agreements. All IPAs have a plan of management, are declared under one or more IUCN categories, and go through a process of public declaration, and are entirely managed by indigenous land owners. IPAs like Nantawarrina and Deen Maar in southern Australia, which were once significantly denuded farm and pastoral lands, are now significantly regenerated, prompting the return of a diversity of native species of flora and fauna (see for example S.Muller 2003; S.Krishnapillai 2000). 


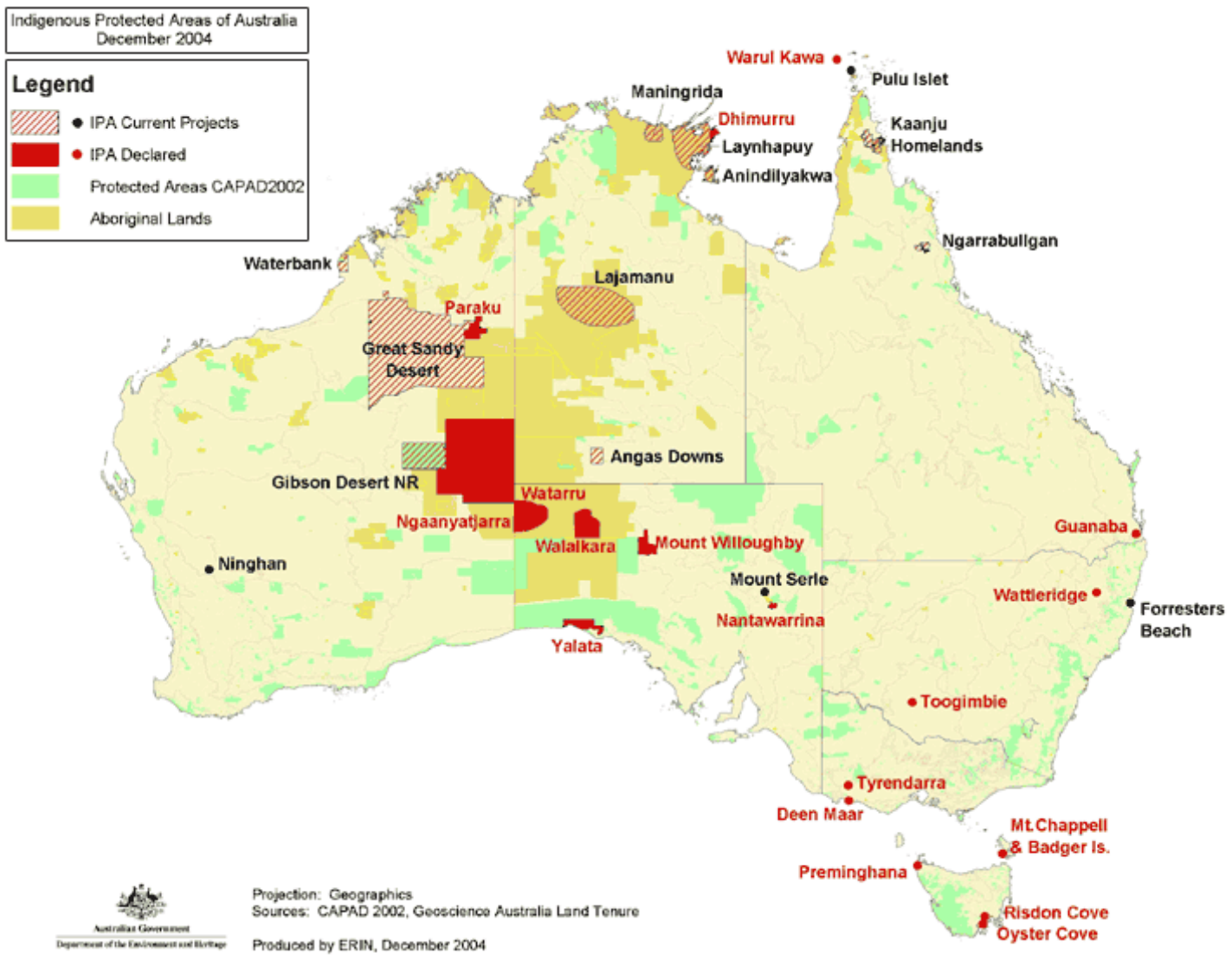

Figure 1: Indigenous Protected Areas of Australia December 2004. Source, with permission: Australian Department of Environment and Heritage. http://www.deh.gov.au/indigenous/ipa/map.html (23 September 2005)

The security and viability of IPAs lies in the establishment of long term land-use agreements offering financial support from the government. ${ }^{17}$ IPAs now constitute 17 per cent of total terrestrial protected area estate in Australia (and this has been achieved since 1998). Average annual funding from the Department of Environment and Heritage to each IPA is A \$110,000 (US\$77, 000) per annum (S.Szabo and D.Smyth 2003: 157). However, at present IPAs offer only short term funding contracts, so that indigenous land management organisations must constantly seek ongoing and additional sources of funding.

The Department of Environment and Heritage is exploring the possibility of introducing a mechanism under which IPAs will eventually be the subject of Ministerial Conservation Agreements under the Environment Protection and Biodiversity Conservation Act:

Government decision makers must be convinced that IPAs function properly, are cost-effective, are essential to the long-term conservation of natural and cultural heritage, and that supporting IPAs is a core responsibility of government conservation agencies (S.Szabo and D.Smyth 2003:160).

17 The history of funding for indigenous land management programs has been fickle even in cases where the program has been judged to be an outstanding success. From 1998 to 2003 the Commonwealth has outlaid A $\$ 6 \mathrm{~m}$ to fund the IPAs and $13.8 \mathrm{~m}$ ha of indigenous land are managed under the IPA program. In contrast the NRS has spent A \$56m between 1998 and 2003 and purchased $6 \mathrm{~m}$ ha of land to be managed as a reserve (at further operating costs to the government) (Szabo \& Smyth 2003). 
The declaration of IPAs and the provision of training and capacity building for IPA managers and annual financial assistance have in many instances had the effect of empowering communities and providing significant environmental, economic, social and cultural benefits. Land management activities range from tourism management and visitor interpretative services to weed and feral animal management and land rehabilitation.

Indigenous land owners participating in the program have also begun entering conservation agreements with state conservation agencies which provide them with additional technical advice, training capacity and access to powers relating to permits and law enforcement on their land. They are also building relationships with other state natural resource management agencies and NGOs, establishing partnerships and participating in joint projects and other activities which both attract additional funding and expand the capacities of land owners to pursue their land management objectives. In some cases indigenous groups are creating arrangements where other bodies such mining and tourism companies with interests in the region contribute funds to enable the management of IPAs and surrounding indigenous lands.

A discussion of some of the key elements and characteristics of two IPAs is provided below. This discussion is informed by fieldwork carried out by the authors in the case of the Dhimurru IPA in the Northern Territory and from findings in project archives and the published literature in the case of the Nantawarrina IPA in South Australia.

\section{Case Study 1}

Declared in August 1998, Nantawarrina was the first IPA declared under the Federal Government's program. The IPA area covers 58,000 hectares and is adjacent to the Gammon Ranges National Park in the northern Flinders Ranges region of South Australia. The local Adnyamathanha community located in Nepabunna in South Australia numbers some 80 people and their local land management organisation manages the land for conservation and cultural values. Title to the land is held by the South Australian Aboriginal Lands Trust (ALT) on behalf of the Adnyamathanha people. In South Australia there has been a long history of negotiated settlements between Aboriginal peoples and the State Government, including for instance those involving the Anangu Pitjantjatjara and the Maralinga Tjarutja peoples (O.Mazel forthcoming). The Aboriginal Lands Trust Act 1966 was the first statutory recognition of Aboriginal land rights in Australia. In areas where legislative title to land has not yet been secured, Aboriginal peoples in South Australia have sought to address their marginalisation in innovative ways (see J.Davies and E.Young 1996; P.Agius et al. 2004).)

In her analysis of the IPA program at Nantawarrina, Samantha Muller refers to it as a part of the ongoing decolonisation of protected areas in Australia. Drawing on the work of Lawrence (1996) she argues that the success of joint indigenous/non-indigenous land management arrangements can best be measured by the extent to which they enable community empowerment, equity and social justice. As noted above, the experience of joint management of national parks in Australia to date has yet to create conclusive outcomes in these areas. ${ }^{18}$ In contrast the available evidence indicates that these measures of success-empowerment, equity and social justice-may be more readily achievable under IPA style arrangements. Rather than government conservation agencies making a 'space' for indigenous involvement (L.Porter 2004) within the framework of their own management models, the IPA program is concerned with creating the conditions for indigenous control of the process from the outset. For example, Muller (2003) reports that the Nantawarrina IPA plan of management was not a plan presented to the community as a finished product for end of process indigenous consultation or negotiation. Rather with advisory assistance from the Federal Department of Environment and Heritage project officers, the Nepabunna community and other Aboriginal representatives from the ALT went through a lengthy planning process which allowed the community to take ownership of the plan from the outset. Following the finalisation of the management plan, the allocation of resources was modelled on the plan under direct community control.

To date the outcomes of the Nantawarrina IPA process have been successful in terms of the improved conservation of the area's cultural and natural values, particularly in relation to revegetation, weed control and feral animal management. To employ a local idiom, 'the country is coming back'. The community is hoping to be able to increase the economic benefit of the land to the community by encouraging tourism. It has been developing small-scale tourism

18 Commenting on the emergence of the IPA program, Muller (2003) notes that while there are currently nine jointly managed national parks and at least 30 under negotiation in Australia, the experience of Aboriginal peoples in these parks has generally been one fraught with political and management tensions, a zone of contested rather than negotiated management. 
infrastructure and a tourism plan is under preparation. ${ }^{19}$

The land covered by the Nantawarrina IPA was returned to the ALT in 1966 under the provisions of the South Australia's Aboriginal Lands Trust Act. Before this the land had been extensively degraded by pastoralism and Muller reports that this damage 'has been exacerbated by exotic species, in particular goats, donkeys and rabbits' (2003: 35). Prior to the declaration of the IPA there was significant pressure by the Upper Flinders Ranges Soil Board to improve the environmental health of the area and the need to access resources to manage the area was a significant part of the community's decision to declare an IPA (S.Muller 2003). The availability of funding is a critical issue for indigenous land managers across the 'indigenous estate', and its absence feeds criticisms by state-agencies about the poor environmental health of areas and the inability of indigenous people to manage the land effectively. Such is the history of relationships between state agencies and indigenous communities, that within the Nepabunna community itself there was initially a degree of community scepticism about the IPA model, based on suspicions that it was in fact a way for the government to surreptitiously take their lands from them (S.Muller 2003). Despite these concerns, the community proceeded with the declaration and two years later they won a United Nations Environment Day award for rehabilitating Nantawarrina (S.Muller 2003). Muller writes that community self-esteem has been significantly boosted by the formal recognition of their land management capacities.

The IPA has also been strengthened by a number of collaborative arrangements with others, including the Federal and State Government's Bounceback 2000 program which targeted feral animal control and revegetation. At the launch of the IPA in 1998, the community also signed an agreement to establish a co-operative relationship with the South Australian Department of Environment and Heritage and Aboriginal Affairs which manages the adjacent Gammon Ranges National Park.

Muller (2003) notes, however, that the community of Nepabunna is as historically contingent in many ways as the IPA itself and that there have been some tensions relating to the rights and interests of Adnyamathanha resident elsewhere to access the land and benefit from the IPA. However, such issues transcend specific concerns about Nantawarrina and are being dealt with at a regional scale by Aboriginal peoples themselves (see for example P.Agius et al. 2004). Gender bias is another issue of concern in the management of the IPA and Muller notes a general tendency for government funded conservation initiatives to enter into arrangements with male-dominated organizations. However, in relation to this issue as well, indigenous organizations engaged in land management across Australia are making a concerted efforts to better integrate women into formal land management activities. ${ }^{20}$

Case Study 2

The Dhimurru Indigenous Protected Area was declared in October 2000. The area covered is over 101,000 hectares of Aboriginal land and sea country (held mainly under ALRA) in north-eastern Arnhem Land region of the Northern Territory. The IPA is managed by the Dhimurru Land Management Aboriginal Corporation (DLMAC) on behalf of the Yolngu traditional owners. Since bauxite mining began in the area in the 1970s an increasingly large non-Yolngu population has moved into the region and DLMAC was established in 1992 to manage the land designated as recreational in the vicinity of the coastal mining township of Nhulunbuy. ${ }^{21}$ The corporation was established by traditional land owners and is directly accountable to them. It has an Executive comprised of nominated representatives from 11 clans that have an interest in the affected lands. A quorum of five committee representatives meets regularly to make operational and administrative decisions on behalf of the members. Prior to conducting any land or sea management activity that will have significant impacts, DLMAC is required to consult with the traditional owners of the country concerned. As DLMAC is directly accountable to traditional owners it must also operate across its jurisdiction in a manner which is sensitive to the roles of pre-existing community organizations with similar functions.

The IPA has an advisory body comprised of the Federal Department of Environment and Heritage, the Parks and Wildlife Commission of the Northern Territory, the Northern Land Council (the Regional Representative Body which administer the ALRA on behalf of Aboriginal traditional owners) and two Yolngu traditional landowners. This arrangement ensures that Yolngu and their advocates have majority representation and it is stipulated that the

19 <http://www.deh.gov.au/indigenous/ipa/declared/nantawarrina.htm> (30 August 2005).

See for example http://www.nlc.org.au/html/care_land.htm> (1 September 2005).

21 Australian Bureau of Statistics Census figures from 2001 indicate that the indigenous population of Nhulunbuy and surrounding regions is approximately 1650, the non-indigenous population of is approximately 3600 with the vast majority of the latter resident in the township itself. The indigenous population of the township is 7\% (ABS 2002). 
Chair must always be a traditional owner. Without a controlling function, the only leverage outside agencies have over the IPA is the threat to withdraw from the process. Given their long standing interest in creating a Northern Territory controlled national park in the region, the Parks and Wildlife Commission of the Northern Territory were initially reluctant participants. They have now, however, signed an agreement with land owners and DLMAC which it is expected will provide for ongoing Yolngu ranger training and the delegation of law enforcement powers. $^{22}$ DLMAC and the IPA are essentially mechanisms for putting in place traditional owners aspirations and concerns for the ongoing management of their lands. They provide Yolngu with ways to manage the land according to customary practices whilst at the same time creating avenues for them to benefit from, and learn, the tools of non-indigenous science (M.Ayre 2002; C.Robinson and N.Munungguritj 2001). Many of the Yolngu rangers who have been employed within the IPA are resource management graduates of an indigenous higher education institution located elsewhere in the Northern Territory. According to the Dhimurru Indigenous Protected Area Management Plan, the guiding principles of Dhimurru are:

- A commitment to the conservation and enhancement of the natural and cultural values of the region while ensuring future management reflects the aspirations of Yolngu (Aboriginal) estate owners;

- A commitment to a representative, Yolngu-controlled, sustainable and collective form of land and sea management, which seeks to devise strategies from a mutual investigation of Ngapaki (white) and Yolngu systems of knowledge;

- A commitment to the continued development of positive interactions with the nonAboriginal world and the sponsoring of co-operative, respectful, educative and mutually beneficial relationships. ${ }^{23}$

The Plan of Management states: 'It is a first principle of the Yolngu decision that participation in an IPA arrangement will not diminish in any way their rights and responsibilities with respect to their lands. ${ }^{24}$ The decision to enter into an IPA arrangement was taken after traditional owners carried out an investigative tour of a number of joint management and community ranger programs across northern Australia. The autonomy and flexibility offered through the IPA program appealed to the traditional owners and DLMAC as it is a model which allows estate owners to maintain their own management discretion, including being able to close areas to public access immediately should the need arise. ${ }^{25}$ This contrasts for example to the situation in jointly managed national parks of Uluru-Kata Tjuta and Kakadu where the approval of the Federal Director of National Parks is required to close, even temporarily, popular tourist sites. ${ }^{26}$

The IPA includes both land and sea areas with significant biodiversity values including feeding and nesting habitat for sea birds and several threatened species of marine turtle. DLMAC activities include managing visitor access and administering a fee paying permit system, rehabilitating damage from past uncontrolled access, wildlife protection, participation in quarantine surveys, visitor interpretations, and research including monitoring the impact of marine debris on threatened turtle populations (see also M.Ayre 2002; R.Kennet and N.Munungurritj 2000; M.Langton 1998; M.Langton et al. 2001; C.Robinson and N.Munungurritj 2001). ${ }^{27}$ DLMAC is also tasked with managing Yolngu impacts on the area and at the direction of traditional estate owners the organization has put in place mechanisms to manage sought after resources such as turtle eggs in areas which are deemed by estate owners to be sensitive to, or affected by, over exploitation.

As the IPA program funding and permit fees for use of the recreational areas within the IPA cover only a portion of operating costs, additional sponsorship provides crucial project specific and other funding support for DLMAC and the IPA. These sponsors include the local bauxite mining company Alcan Gove and a range of environmental organizations such as World Wide Fund for Nature, Australian Conservation Volunteers and the Threatened Species

22 See $<$ http://www.atns.net.au/biogs/A001063b.html $>$ (30 August 2003).

See $<$ http://www.atns.net.au/biogs/A000469b.htm> (30 August 2005).

<http://www.atns.net.au/biogs/A000453b.html> (30 August 2005).

For example following the death of an elder.

See for example 'Temporary Closure of Uluru Climb' at

$<$ http://www.deh.gov.au/media/dept-mr/dp24nov04.htm> (30 August 2005).

The tourist climb to the top of Uluru monolith is a contentious issue in any case, given that traditional owners have expressly stated that they would prefer tourists not to climb Uluru at all. However, the joint management situation is such that this is stated only as a preference not as a legally enforceable prohibition.

<http://www.atns.net.au/biogs/A000453b.html> (30 August 2005). 
Network. ${ }^{28}$ When DLMAC was first established it was the local estate owning organizations who initially funded the organization over a two year period. Later, this show of community support and the achievements of the organisation attracted other support from Federally funded conservation programs and the local mining company. Dhimurru's "both ways approach" has meant that the role of the Executive officer (who to date has always been a non-Yolngu) has been pivotal to accessing alternative sources of funding, writing grant applications and reporting on expenditures to existing funding sources. This position works alongside the Director (who conversely has always been a Yolngu) who oversees Yolngu aspects of the organisations and the critical interface between cultures. Formally declared eight years after the establishment of DLMAC, one of the advantages of the Dhimurru IPA is that it provided the organization with a relatively stable and streamlined source of funding to manage their core land management business. At the same time, it provided DLMAC with a level of financial viability and institutional legitimacy through which it could attract funding from other sources in order to fund additional activities.

Currently the IPA program assists in the payment of the salary of four Yolngu staff including the Director. Two Ranger positions are funded through the NHT as part of a Yellow Crazy Ant eradication campaign. Four ranger positions are funded through other programs including the local Community Development Employment Program (essentially a government funded work for welfare scheme). The Executive Officer, the Permits Officer and the Accounts Officer salaries are paid in large part by contributions from the local mining company and income from access permit fees. While DLMAC operates on the assumption that the IPA program will continue to be funded, as noted above IPAs are only funded on an annual basis. The relative precariousness of these funding arrangements compared to the formalised ongoing government commitments provided to jointly managed national parks was a trade-off considered carefully by Yolngu estate owners when they made the decision to pursue the IPA model. In the face of what was at times a very vocal local and Northern Territory-level nonAboriginal opposition to the creation of the IPA, senior traditional owners were adamant from the outset that this was the correct pathway.

The key points that emerge from this discussion of IPAs are the foundational principles of indigenous control and voluntary participation that underpin the program. The success of the two IPAs discussed is grounded in principles that have implications beyond the details or even the funding sustainability of the particular conservation model at work-in this case the IPA program. ${ }^{29}$ For many remote area indigenous estate owning communities in Australia, participation in the conservation sector is one of the only alternatives available to support rural livelihoods. Where the aspirations of local Aboriginal peoples are to make a living off country, participation in the nation's conservation sector generally, and the IPA program specifically, can provide people with a mechanism to pursue these goals. Arguably, in these cases, the principles of the IPA program should underpin all other conservation-oriented programs on indigenous lands.

It is clear from the above examples that to some extent the idea of protected areas in Australia has shifted from a 'nature only' approach, to a concept of protected areas for which the central tenets are natural and cultural resource management regimes governed by local communities in pursuit of environmental security and sustainable economic livelihoods. As has been discussed earlier, this trend is also evident globally.

$28 \quad<$ http://members.iinet.net.au/ dhimurru/sponsor.htm> (30 August 2005).

The history of funding for indigenous land management programs has been fickle even in cases where the program has been judged to be an outstanding success. For example the IPA program was preceded by CEPANCRM (Contract Employment Program for Aboriginals in Natural and Cultural Resource Management) program. Beginning in 1987-88 CEPANCRM provided environmental employment opportunities for Indigenous people throughout Australia. The program was given further impetus, funding and support following the recommendations of the Royal Commission into Aboriginal Deaths in Custody in 1992-1993. It was widely recognized for the contribution it made to environmental management and the social, cultural and economic objectives (including education participation and outcomes) encompassed in many Government initiatives dealing with indigenous issues (R.Breckwoldt et al. 1997: 9). However, when the conservative Federal Coalition Government came to power in 1996 the program was cut, despite its success. Nevertheless the legacy of the program has influenced the success and capacity building capabilities of many of the indigenous organizations now participating in the IPA program. 


\section{The Significance of Community-Oriented Protected Areas}

The Australian IPA program may offer some critical ideas for the development of community oriented protected areas elsewhere. Despite cynicism about the nexus of relationships between nation states, indigenous/local community struggles and donor agendas, the niche opened up by the ideology of community-oriented protected areas is significant. They can, if they involve adequate recognition of the relevant political and economic rights and interests of indigenous peoples and local communities, play a role in the maintenance of the biodiversity related knowledge systems of these groups and, by extension, secure their capacity to control an economically sustainable future through both customary subsistence activities and the negotiated development of their resources within the market economy. Where there is the political and legal will to recognise, support and engage with indigenous governance structures in the protection of biodiverse ecosystems there are potentially a myriad of positive outcomes for both conservation and sustainable economic and cultural livelihoods. As Phillips explains:

...the importance of CCAs [Community Conserved Areas] is considerable, for they are far more common than was until recently appreciated. In South Asia, it is estimated that there are many thousand such areas under community protection... They exist too as sacred groves in Africa, as 'tapu' areas in the South Pacific, and as 'hema' reserves in pastoral communities of west Asia. They are common from the Arctic to the tropical rain forests, where indigenous peoples have long lived close to nature. When the efforts of local people to conserve their own environments go un-recognised and unsupported, it means that a major contribution to conservation is being neglected (2003: 17).

The well-being of large human populations is at stake because of the potential for widespread loss of traditional and indigenous biodiversity related knowledge and natural resource management systems. These losses are occurring as a result of territorial demise and inappropriate land management systems, diminishing natural resources through overexploitation, particularly land clearing and commercial forestation, the spread of urban conglomerates, rapid social and cultural change as a result of economic development, population transfers for development projects, and other factors. Forests, fisheries, water resources and waterways are particularly at risk.

In many cases, as we have discussed in this paper, these risks are acknowledged by nation states, and it is noteworthy that cooperative arrangements between development agencies, NGOs and countries has led to the identification of such risks and the initiation of programs to preserve traditional knowledge and practices to sustain the livelihoods of local communities and indigenous people. Although it must also be noted that for many developing nation governments, as Li suggests in the case of Indonesia, it is likely that they have in fact been 'forced to pay attention to the conservation agenda of the donors and show a progressive face by passing new environmental laws, participating at Rio, and ... agreeing that some people have such unique and special environmental knowledge that it should indeed be protected' (T.M.Li 2003: 389-390, emphasis in the original). Nature conservation, as Li notes, has a 'powerful international constituency' (2003: 390; see also A.L.Tsing 2005).

The success of programs like the IPA program in Australia lies in access to guaranteed land security and the ability of indigenous people to exercise their own governance structures whilst at the same time accessing the multiplicity of linkages with outside agencies which can assist them to achieve their economic sustainability and land management goals. The IPAs provide a basis whereby indigenous people can have informed choices about how they exercise their rights and interests in their traditional lifeways and also in creating the capacity for a sustainable economic base for their communities within the modern market economy. The IPAs program has resulted, for example, in the establishment or strengthening of land management organisations which have provided the community with employment, increased self esteem, and provided an organisation structure which encourages intergenerational dialogue between elders and the youth who are seeking to understand more about their country and the stories and knowledge of the old people. For instance, when traditional owners are able to involve their children in field trips, they are also transferring knowledge across generations and in many cases strengthening the knowledge of local languages. In some cases, they have been able to reestablish traditional burning practices, maintain waterholes, reduce feral animal impacts, and ensure the maintenance of these traditions by promoting renewed interest among younger generations in 'caring for country' (S.Szabo and D.Smyth 2003: 155).

Effectively, an IPA can only be achieved where there indigenous people have exclusive title to their land. While there have been a number of projects where indigenous 
groups have been funded to negotiate with state agencies in existing state owned national parks and reserves these have generally been less successful for a number of reasons:

- The entrenched power of state conservation agencies

- Lack of commitment by states

- The lack of a relationship between indigenous groups and state conservation agencies from which to pursue in any practical ways the rhetoric of engagement.

However this situation is improving as the necessary inter-personal conservation agency/community relationships start to gain substance at the ground level. Moreover, if the existing IPAs continue to deliver successful conservation and community development outcomes they will increasingly become attractive land management models for state conservation agencies.

In addition to the need for the legal recognition and protection of indigenous property and resource rights, it is also crucially important that nation states recognise and respect divergent governance processes, 'the practices, mechanisms, techniques and social institutions that influence and regulate conduct' (G.Nettheim et al. 2002: 377). Indigenous people, particularly those who have maintained a degree of control over their land or sea estates draw from their own governance structures and decision-making processes and protocols when managing their estates. As the cases discussed in this paper demonstrate, the recognition of this jurisdiction is of paramount importance in successful land management arrangements for indigenous and local peoples. Recognising the centrality of land security and the ability of indigenous and local groups to govern their own affairs allows them opportunity to utilise, protect and enhance their traditional knowledge and customary land management practices according to their own style of governance and economic needs.

\section{Conclusion}

In contrast to the critiques of community-based conservation now prevalent in the social sciences literature, we have argued, using evidence from case studies, that communityoriented protected areas are delivering significant benefits to indigenous peoples in Australia. We have identified the reasons for the success of such programs-access to guaranteed land security and the ability of indigenous people to exercise their own governance structures and decision-making authority whilst drawing on the power of 'engaged universals' (A.L.Tsing 2005) to create and access multi-scalar linkages which can assist indigenous peoples to achieve their livelihood and environmental management goals.

At the international level, intergovernmental co-operation under the auspices of a large number of international agencies has established an 'in-principle' emerging framework that recognises the need to protect, preserve and maintain the lifeways and territories of indigenous peoples and local communities. In addition to issue of human rights, concerns about the ecological health of the planet, and its relationship to the food security of large human populations, have aided the recognition of the importance of traditional biodiversity related knowledge. Further, it recognises the rights of holders of such critical knowledge to use such knowledge to enable them to create economic sustainability for their communities within the global market economy.

At the national level, without rights to traditional estates, the continued existence of indigenous peoples and local communities is at risk. The displacement of indigenous peoples and local communities in the wake of large scale development projects and industrial resource use is well documented. A preliminary step to ensuring the continued existence of traditional knowledge must be that indigenous people and local communities have secure tenure so that they can maintain, cultivate and continually renew their traditional knowledge. In addition, the existence of indigenous peoples and local communities and their sui generis rights and interests are becoming recognised in domestic constitutional and legislative ways.

The concepts of sustainable development and biodiversity are discourses which articulate 'a new relation between nature and society on global contexts of science, cultures, and economies' (A.Escobar 1998: 55). These new understandings of relationship between nature and society need to also recognise that environmental knowledge is 'embodied and practiced' rather than simply 'shared and context-free' (A.Escobar 1998: 62). The traditional biodiversity related knowledge of indigenous peoples and local communities is renewed, elaborated and maintained through continuing practices of land and sea management and governance of biological resources. Community-oriented protected areas provide the essential territorial spaces which can assist in achieving the CBD's aim of respecting, preserving and maintaining the knowledge and innovations and practices of indigenous peoples and local communities in order to promote the conservation and sustainable use of biological diversity. 
From the perspective of indigenous peoples and local communities, for whom basic subsistence activities are either the predominant way of life or a significant part of their economic activities, the maintenance and preservation of their traditional biodiversity related knowledge traditions and applications is essential to safeguard food security and the provision of other basic economic and cultural needs. Community-oriented protected areas can be used by local communities and indigenous peoples to aid in securing their territorial base, reaffirming cultural identities and guaranteeing some degree of autonomy over the governance of biological resources. They also provide communities with the opportunity to renew and/or continue to support the biodiversity management systems which have underpinned their traditional livelihoods. For these reasons community-oriented protected areas under the control of the relevant indigenous and/or local groups are measures which can assist in the preservation and maintenance of traditional knowledge and also help carry forward the process of re-envisioning the concept of biodiversity to include the diversity of ecocultural practices, and the complex social and political circumstances in which they occur.

\section{References Cited}

Aboriginal and Torres Strait Islander Commissioner and Lingiari Foundation Partnership. Indigenous Rights to Waters Report and Recommendations. Canberra: Aboriginal and Torres Strait Islander Commissioner, 2002.

ABS (Australian Bureau of Statistics). Population Distribution: Aboriginal and Torres Strait Islander Australians. 2001. ABS Catalogue No. 4705.0, 2002.

Adams, W., Aveling, R., Brockington, D., Dickson, B., Elliott, J., Hutton, J., Roe, D., Vira, B., and Wolmer, W.

"Biodiversity Conservation and the Eradication of Poverty." in Science (2004)12 November: 1146-1149.

Adams, W. and Mulligan, M.(eds).

Decolonizing Nature: Strategies for Conservation in a Post-colonial Era. London: Earthscan, 2003.

Agius, P., Davies, J., Howitt, R., Jarvis, S., and Williams, R.,

"Comprehensive Native Title Negotiations in South Australia." In Honour Among Nations? Treaties and Agreements with Indigenous People, edited by M.Langton,, M. Tehan, L. Palmer and K. Shain, 203-219. Melbourne University Press, Melbourne, 2004.

Agrawal, A.

"Dismantling the Divide Between Indigenous and Scientific Knowledge." Development and Change 26 (1995): 413-439.

Agrawal, A. and Redford, K.

"Poverty alleviation and biodiversity conservation: Shooting in the dark." University of Michigan, SNRE and Wildlife conservation society [online], 2005. http://polisci.ucsd.edu/calendar/kent-arunpaperdraft6a.pdf (6 September 2005).

Agrawal, A. and Ribot J.C.

"Accountability in Decentralization: A Framework with South Asian and West African Cases.” World Resources Institute, 2000.

Altman, J.

Hunter-gatherers today: An Aboriginal economy in north Australia. Canberra: Australian Institute of Aboriginal Studies, 1987.

"The Political Economy of a Treaty: Opportunities and Challenges for Enhancing

Economic Development for indigenous Australians.” The Drawing Board: An Australian Review of Public Affairs 3 no.1 (2002): 65-81.

<http://www.econ.usyd.edu.au/drawingboard/journal/0211/altman.pdf $>$ (26 February 2004).

"People on country, healthy landscapes and sustainable indigenous economic futures: The Arnhem Land case.” The Drawing Board: An Australian Review of Public Affairs 4 no.2 (2003): 65-82.

$<$ http://www.econ.usyd.edu.au/drawingboard/journal/0311/altman.pdf $>$ (26 February

Anderson, B. 2004)

"Nationalism and Cultural Survival in Our Time: A Sketch." In At Risk of Being Heard: Identity, Indigenous Rights, and Postcolonial States edited B. Dean and J. Levi, Ayre, M. 165-190. Ann Arbor: The University of Michigan Press, 2003.

"Yolngu places and people: taking aboriginal understandings seriously in land and sea 
Beltran, J. (ed.)

management”. Ph.D., The University of Melbourne, 2002.

Indigenous and Traditional Peoples and Protected Areas: Principles, Guidelines and Case Studies. World Commission on Protected Areas Best Practice Protected Area Berkes, F.

Guidelines Series No. 4, IUCN-The World Conservation Union, 2000.

“Rethinking Community-Based Conservation”. Conservation Biology 18 no.3 (2004): 621-630.

Blaser, $\mathrm{M}$.

"Life Projects: Indigenous Peoples' agency and development." In In the Way of Development: Indigenous Peoples, Life Projects and Globalization edited by $\mathrm{M}$. Blaser, H. Feit and G. McRae, 26-44. Zed Books, London, 2004.

Breckwoldt, R., Boden, R. and Williams, R.

Contract Employment Program for Aboriginals in Natural and Cultural Resource Management (CEPANCRM): Evaluation biodiversity group-Environment Australia.

Brosius, $\mathrm{P}$ Canberra: Environment Australia, 1997.

Chapin, M

"Indigenous Peoples and Protected Areas at the World Parks Congress.” Conservation Biology 18 no.3 (2004) June: 609-612.

Colchester, $\mathrm{M}$.

“A Challenge to conservationists.” Worldwatch Magazine (2004): 17-31.

"Unity and Diversity: Indonesian policy towards tribal peoples." The Ecologist,16 no.2/3 (1986): 89-98.

"Indigenous Peoples and Biodiversity Conservation; Sector Review for the Biodiversity Support Program: Global Overview and South and South East Asia Review.” Unpublished paper, 2000.

"Conservation policy and Indigenous peoples.” Environmental Science and Policy, 7 (2004): 145-153.

Commonwealth of Australia

The National Strategy for the Conservation of Australia's Biological Diversity. Canberra: Commonwealth Department of Environment, Sport and Territories, 1996.

Convention on Biological Diversity

<http://www.biodiv.org/convention/articles.asp $>$ (19 May 2004)

Davies, J. and Young, E.

“Taking Centre Stage: Aboriginal strategies for redressing marginalisation”, in Resources, Nations and Indigenous Peoples; Case Studies from Australasia, Melanesia and Southeast Asia edited by R. Howitt et al., 152-171. Melbourne: Oxford University Press, 1996.

Dean, B. and Levi, J. (eds)

At Risk of Being Heard: Identity, Indigenous Rights, and Postcolonial States. Ann Arbor: The University of Michigan Press, 2003.

Dorsett, S. and Godden, L.

A Guide to Overseas Precedents of Relevance to Native Title. Canberra: Native Title Research Unit, AIATSIS, 1998.

Dunn, J.

East Timor: A rough passage to Independence. Third Edition, Double Bay, NSW: Longueville Books, 2003.

Endicott, K.

"Indigenous Rights Issues in Malaysia." In At Risk of Being Heard: Identity, Indigenous Rights, and Postcolonial States, edited by B. Dean and J. Levi, 142-164. Ann Arbor: The University of Michigan Press, 2003.

Escobar, A.

"Whose Knowledge, Whose nature? Biodiversity, Conservation, and the Political Ecology of Social Movements.” Journal of Political Ecology 5 (1998): 53-80.

Ferrari, M.F.,

Protecting Biodiversity and Indigenous Peoples/Local Communities' Rights: the Challenge in Southeast Asia, IUCN Theme on Indigenous/Local Communities, Equity Fitzpatrick, D. and Protected Areas (TILCEPA), unpublished manuscript, no date.

Fitzpatrick, D

Land Claims in Timor Leste. Canberra: Asia Pacific Press, 2002.

“'Best Practice' Options for the Legal Recognition of Customary Tenure.” 
Development and Change 36 no.3 (2005): 445-495.

Fox, J and Soares, D. B. (eds).

Out of the Ashes: Destruction and Reconstruction of Timor Leste. Adelaide: Crawford

Ghai, D. (ed.) House Publishing, 2000

Goodman, J.

Development and Environment: Sustaining People and Nature. Oxford, UK: Blackwell Publishers, 1994.

“Indonesians for East Timor.” Inside Indonesia 59 (1999) July-September, no page. Available at <http://www.insideindonesia.org/edit59/goodm.htm> (23 September 2005).

Hassall and Associates.

"Evaluation of the NHT Phase 1 Facilitator, Coordinator and Community Support Networks", report prepared for Environment Australia and Commonwealth

Hunt, J. Department of Agriculture, Fisheries, Forestry, 2003.

“Building a New Society: NGOs in Timor Leste.” New Community Quarterly 2 no.1 (2004)

Igoe, J.

Conservation and Globalization: A Study of National Parks and Indigenous Communities from East Africa to South Dakota. Wadsworth Thomson Learning, CA, 2004.

Indigenous Land Corporation.

Annual Report 1996-1997. Adelaide: ILC, 1997.

Indigenous Land Corporation Corporate Plan 2003 - 2006, 2003a. Available at

<http://www.ilc.gov.au/PDF/CorpPlan.pdf.> (20 May 2004)

2003b. Available at <http://www.ilc.gov.au/> (20 May 2004)

Jaireth, H. and Smyth, D. (eds)

Innovative Governance: Indigenous Peoples, Local Communities and Protected Areas.

New Delhi: Ane Books, 2003.

Kennet, R., and Munungguritj, N.

"Looking after miyapunu: Indigenous management of marine turtles", in Protected Area Management, Principles and Practice, edited by G. Worboys. Sydney: Oxford University Press, 2000.

Kehi, B.

"Friendship City Relations Between Communities and Local Governments in Australia and in Timor Leste: People-Oriented Relations.” ATNS, 2005. Forthcoming at $<$ http://www.atns.net.au/papers.php>

King, V.T.

"Indigenous Peoples and Land Rights in Sarawak, Malaysia: To be or not to be a Bumiputra.” In Indigenous peoples of Asia, edited by R.H. Barnes, A. Gray, and B. Kingsbury, 13-34. Ann Arbor: Association for Asian Studies, 1995.

Kothari, A.

“Community-oriented Conservation Legislation: Is South Asia Getting Somewhere?”

In Innovative Governance: indigenous Peoples, Local Communities and Protected Areas, edited by H. Jaireth and D. Smyth, 61-84. New Dehli: Ane Books, 2003. pp. 6184.

“Displacement Fears.” Frontline 21 no. 26 (2004), December 18-31: no page.

Krishnapillai, S.

"Sharing the Land: The Deen Maar Indigenous Protected Area". Arena Magazine 48 (2000): 31-34.

Langton, $\mathrm{M}$.

Burning Questions: Emerging Environmental Issues for Indigenous Peoples in Northern Australia. Darwin Centre for Indigenous Natural and Cultural Resource Management, Northern Territory University, 1998.

"The 'Wild', the Market, and the Native: Indigenous People Face New forms of Global Colonization.” In Globalization , Globalism, Environments, and Environmentalism. Consciousness of Connections, The Linacre Lectures, edited by S.Vertovec and D.Posey, 141-167. Oxford: Oxford University Press, 2003.

Langton, M., Cooke, P., Davies, J., Epworth, D., Leach, K., Mackinolty, C., Sinnamon, S., Storrs, M. and Young, E.

Indigenous Social, Economic and Cultural Issues in Land, Water and Biodiversity Conservation: A Scoping Study for WWF Australia, unpublished report on behalf of the Centre for Indigenous Natural and Cultural Resource Management, NTU, Darwin, 
1999.

Langton M. and Ma Rhea, Z.

"Traditional Lifestyles and Biodiversity Use Regional Report: Australia, Asia and the Middle East. Composite Report on the Status and Trends Regarding the Knowledge, Innovations and Practices of Indigenous and Local Communities Relevant to the Conservation and Sustainable Use of Biodiversity", Prepared for the Secretariat of the Convention on Biological Diversity, Montreal. UNEP/CBD/WG8J/3/INF/4, 2003. Available at <www.biodiv.org/doc/meetings/tk/wg8j-03/ information/wg8j-03-inf-04en.doc> (20 May 2004)

Langton, M. and Palmer, L.

"Indigenous People and Modern Agreement Making in Australia: Issues and Trends." Australian Indigenous Law Reporter, 8 no. 1 (2003): 1-31.

Lawrence, D.

"Managing Parks/Managing Country: Joint Management of Aboriginal Owned Protected Areas in Australia.” Research Paper 2 1996-1997, Canberra: Department of the Parliament Library, 1996.

Kakadu: The Making of a National Park. Carlton The Miegunyah Press, Melbourne University Press, 2000.

Li, T. M. (ed.)

Transforming the Indonesian Uplands. New York: Routledge, 1999.

Li, T.M.

"Masyarakat Adat, Difference, and the Limits of Recognition in Indonesia's Forest Zone.” In Race, Nature, and the Politics of Difference, edited by D. Moore, J. Kosek, and A. Pandian, 380-406. Durham and London: Duke University Press, 2003.

Maffi, L. (ed.)

On Biocultural Diversity: Linking Language, Knowledge and the Environment. Washington D.C.: Smithsonian Institution Press, 2001.

Magome, H. and Murombedzi, J.

"Sharing South African National Parks: Community Land and Conservation in a Democratic South Africa.” In Decolonizing Nature: Strategies for Conservation in a Post-colonial Era, edited by W. Adams and M. Mulligan, 108-134. London: Earthscan, 2003.

Ma Rhea, Z.

"Raising awareness of indigenous knowledge in science and technology education", (2004) Available at http://www.scidev.net/dossiers/index.cfm?fuseaction=policybrief\&dossier=7\&policy= $\underline{35}$ (27 January 2004).

Martinez Cobo, J. R.

"Study of the Problem of Discrimination against Indigenous Populations". Volume 5, Mathias, E. UN doc. E/CN.4/Sub.2/1986/7/Add.4, 1987.

Indigenous Knowledge and Sustainable Development. IIRR Working Paper. Silang, Cavite, Philippines: International Institute of Rural Reconstruction, 1994.

"Recording indigenous knowledge: an overview." In Indigenous Knowledge in Conservation of Crop Genetic Resources, edited by J. Schneider. Indonesia: CIPESEAP/CRIFC., 1995.

Matowanyika J., Garibaldi V., and Musimwa E. (eds)

Indigenous Knowledge Systems and Natural Resource Management in Southern Africa. Harare, Zimbabwe: IUCN, 1995.

Maundu, $\mathrm{P}$.

"Methodology for collecting and sharing indigenous knowledge: a case study."

Mazel, O.

Indigenous Knowledge and Development Monitor 3 no.2 (1995).

"Returning parna wiru: Restitution of the Maralinga Lands to Traditional Owners in South Australia.” In Settling with Indigenous People, edited by M. Langton, O. Mazel, L. Palmer, K. Shain, K., and M. Tehan. Annandale, NSW: Federation Press. Forthcoming 2006.

McWilliam, A.

“Timorese Seascapes: Perspective’s on customary marine tenures in Timor Leste.” The Asia Pacific Journal of Anthropology 3 no.2 (2002): 6-32

"New Beginnings in Timor Leste's Forest Management.” Journal of South East Asian Studies 34 no.2 (2003):307-327.

"Fataluku Forest Tenures and the Conis Santana National Park in East Timor." In

Sharing the Earth, Dividing the Land: Territorial Categories and Institutions in the 
Muller, S

Austronesian World. Edited by T. Reuter. Sydney: Pandanus Press, 2006.

"Towards Decolonisation of Australia's Protected Area Management: The Nantawarrina Indigenous Protected Area Experience.” Australian Geographical Studies 41 no.1 (2003): 29-43.

National Native Title Tribunal.

What does the indigenous Land Corporation Do?, NNTT, 2003. Available at $<$ http://www.nntt.gov.au/publications/data/files/NTF_5f.pdf> (20 May 2004)

Niezen, R.

The Origins of Indigenism: Human Rights and the Politics of Identity. Berkeley: University of California Press, 2003.

A World Beyond Difference: Cultural Identity in an Age of Globalization. MA: Blackwell Publishing, 2004.

Nettheim, G., Meyers, G., and Craig, D.

Indigenous Peoples and Governance Structures: A Comparative Analysis of Land and Resource Management Rights. Canberra: Aboriginal Studies Press and AIATSIS, 2002.

New Zealand Biodiversity Strategy, no date.

Available at <http://www.biodiversity.govt.nz/picture/doing/nzbs/> (14 September 2004)

Nietschmann, B.Q.

The Interdependence of Biological and Cultural Diversity, Centre for World Indigenous Studies, Occasional Paper 21, Kenmore WA, 1992.

Ospina, S. and Hohe, T.

Traditional Power Structures and Local Governance in Timor Leste: A Case Study of the Community Empowerment Project (CEP). Etudes Courtes No. 5, Graduate Institute

Palmer, L. of Development Studies, Geneva, 2002.

"Fishing Lifestyles: 'Territorians', Traditional Owners and the Management of Recreational Fishing in Kakadu National Park.” Australian Geographical Studies, 42 no. 1 (2004a): 60-76.

"Bushwalking in Kakadu: A Study of Cultural Borderlands." Social and Cultural Peluso, N. Geography, 5 no.1 (2004b): 109-128.

Rich Forests, Poor People: Resource Control and Resistance in Java. Berkeley: University of California Press, 1992.

"Coercing Conservation? The Politics of State Resource Control". Global Environmental Change 3 no.2 (1993): 199-217.

"Whose Woods Are These? Counter-Mapping Forest Territories in Kalimantan, Phillips, A. Indonesia.” Antipode 27 no.4 (1995): 383-406.

“Turning Ideas on their Head' The New Paradigm for Protected Areas.” In Innovative Governance: Indigenous Peoples, Local Communities and Protected Areas, edited by Porter, L. H. Jaireth and D. Smyth, 1-28. New Delhi: Ane Books, 2003.

"Planning's Colonial Culture : An Investigation of the Contested Process of Producing Posey, D. A. Place in (post)colonial Victoria.” Ph.D., The University of Melbourne, 2004.

"Fragmenting Cosmic Connections: Converting Nature Into Commodity." In Globalization , Globalism, Environments, and Environmentalism. Consciousness of Connections, The Linacre Lectures, edited by S. Vertovec and D. Posey 123-140. Povinelli, E. Oxford: Oxford University Press, 2003.

Labor's Lot: The Power, History, and Culture of Aboriginal Action. Chicago: The Power, $\mathrm{T}$. University of Chicago Press, 1993.

"Joint management at Uluru-Kata Tjuta National Park." Environmental and Planning Law Journal, 19 no. 4 (2002): 284-302

Redford, K.H. and Sanderson, S.E. Richards, P. "Extracting Humans from Nature.” Conservation Biology 14 (2000): 1362-4.

Indigenous Agricultural revolution: Ecology and food production in West Africa. London: Hutchinson, 1995 
Robinson C., and Munungguritj, N.

"Sustainable Balance: A Yolngu Framework for Cross-cultural Collaboration.” In Working on Country: Contemporary Indigenous Management of Australia's Lands and Coastal Regions, edited by R. Baker, J. Davies and E. Young, 92-107. Melbourne: Ruddle, K. Oxford University Press, 2001.

"External Forces and Change in Traditional Community-based Fishery Management Systems in the Asia-Pacific Region.” MAST (Maritime Anthropological Studies) 6 (1993a): 1-37.

"Local Knowledge in the Future Management of Inshore Tropical Marine Resources and Environments.” Nature and Resources 29 no.4 (1993b).

Traditional Community-Based Marine Resource Management Systems in the AsiaPacific Region: Status and Potential, Manila. Philippines: International Centre for Living Aquatic Resources Management (ICLARM), 1994.

Ruddle, K., Hviding, E., Johannes, R. E.

"Marine resources management in the context of customary tenure." Marine Resource Economics 7 (1992): 249-73.

Ruddle, K. and Johannes, R. (eds)

Traditional Marine Resource Management in the Pacific Basin: an Anthology. Jakarta: UNESCO-ROSTSEA, 1990.

Smyth, D.

"Protecting Country-Indigenous Protected areas Phase Two Report", Consultancy Report prepared for the Australian Nature Conservation Agency, Canberra, 1995.

Smyth, D. and Sutherland, J.

Indigenous Protected Areas: Conservation Partnerships with Indigenous Landholders. Canberra: Environment Australia, 1996.

Solomon, M.

"Traditional Lifestyles and Biodiversity Use Regional Report: Pacific, Composite Report on the Status and Trends Regarding the Knowledge, Innovations and Practices of indigenous and Local Communities”, Prepared for the Secretariat of the Convention on Biological Diversity, Montreal, 2003.

Szabo, S. and Smyth, D.

"Indigenous Protected areas in Australia: Incorporating indigenous Owned Land into Australia's National System of Protected Areas", in Innovative Governance: Indigenous Peoples, Local Communities and Protected Areas, edited by H. Jaireth, and D. Smyth, 145-164. New Delhi: Ane Books, 2003.

Tehan, M.

"A Hope Disillusioned, an Opportunity Lost? Reflections on Common Law Native Title and Ten years of the Native Title Act.” Melbourne University Law Review 27 no.2 (2003): 523-571.

Timor-Leste National Planning Commission.

National Vision. Dili: Democratic Republic of Timor-Leste, 2002. Available at $<$ http://siteresources.worldbank.org/INTTIMORLESTE/Resources/Our\%2BNation\%2 BVision.pdf $>$ (11 September 2004)

Thongchai, W.

Siam Mapped: A History of the Geo-Body of a Nation. Honolulu: University of Hawaii Press, 1994.

Tsing, A. L.

Friction: An Ethnography of Global Connection. Princeton and Oxford: Princeton University Press, 2005.

UNESCO/CSI.

Thailand's sea nomads, UNESCO/CSI 2000. Available at

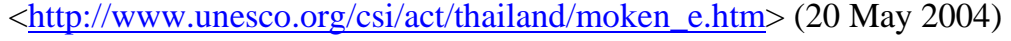




\begin{abstract}
Across the globe, community-oriented protected areas are increasingly recognised as an effective way to support the preservation and maintenance of the traditional biodiversity related knowledge of indigenous peoples and local communities. We argue that guaranteed land security and the ability of indigenous and local peoples to exercise their own governance structures is central to the success of community-oriented protected area programs. In particular, we examine the conservation and community development outcomes of the Indigenous Protected Area program in Australia, which is based on the premise that indigenous landowners exercise effective control over environmental governance, including management plans, within their jurisdiction (whether customary or state-based or a combination of elements of both), and have effective control of access to their lands, waters and resources.
\end{abstract}

Key Words: community-oriented protected areas, Indigenous rights, conservation, Australia

\title{
Abstract in French
}

\section{Abstract in Spanish}

